\title{
The Demographic, Legal and Managerial Aspects in the Growth of Insurance Business in Bangladesh
}

\author{
Abdul Latif \\ Associate Professor \& Head \\ Department of Business Administration \\ Sylhet International University, Bangladesh \\ novalatif@gmail.com \\ Abul Hasanat Ibn Abedin \\ Assistant Professor \& Head (Acting) \\ Department of Law and Justice, North East \\ University Bangladesh \\ ahibnabedin1984@yahoo.com
}

\section{Ahmed-Al-Hamid}

Researcher, Advanced Education and Research Center

Nayasarak, Sylhet

\begin{abstract}
Insurance business is found as important supporting business in expediting the economy by covering the risk of lives and assets. The growth in insurance business is the indicator of economic growth in every country. The awareness and confidence in insurance business is important as it is a long term contract between policy holders and insurers. Besides the demographic, financial and managerial factors are to be considered in utilizing the prospects of that business in an economy of very poor penetration ratio. The objective of the research is to find the demographic and financial factors of policyholders and the managerial factors of insurers along with the legal support of an economy in the growth of insurance business by continuation of insurance policies to get the benefits and create more awareness to the mass populations. This descriptive analytical research was done by survey technique with well-structured questionnaire to collect primary data. The collected data were analyzed by using simple statistical methods, cross tabulation and chi-square analysis. The findings highlighted the impact of laws on development of insurance business. To utilize the opportunities, the awareness and confidence on insurance must be built up. The demographic and financial factors of prospects should be analyzed as some elements may discourage penetration ratio and encourage lapse ratio. The managerial aspects must play the highest role in availing the opportunity of huge insurance business in this country by attracting and restoring the prospects.
\end{abstract}

Keywords: Demographic and Financial factor of policyholders, managerial factors of insurers, penetration ratio. Legal development

\section{INTRODUCTION}

Insurance is the contract between insurer and insurance holders where insurer takes the specific risks of policy holders in exchange of specific amount (premium) in specific interval of time as per the contract. To make this contract legal, the applications of laws were found from long being to control and regulate the insurance business. To some extent, insurance free people who feel some sort of anxieties from uncertainty. But people of Bangladesh do not like to do insurance in satisfactory level. It may because of their unawareness, lack of confidence, lack of legal support in getting compensation etc. These problems are derived from competitions among insurance companies and the legal framework to support the competition and protect the customers etc. Insurance contract were formulated and conducted according to the Contract Act of 1872 in Indian subcontinent. But with the increasing demand of insurance to cover the risk of lives and assets, separate laws were needed afterwards. To meet these needs, two separate laws were passed in 1912 (Repealed) and modified in 1928 (Repealed) and 1938 (Repealed). These laws were prevailing with more modification with the need of times. First insurance company was established in 1818 in the name of 'The Oriental Life Insurance Company. In the time of Independence of Bangladesh, there were 67 insurance companies working in Bangladesh. Of them, 15 were established by Bangladeshi owners, 29 were of Pakistani and 23 from other countries. In 1972 according to the Presidential Order 95 all the insurance companies were owned by the Govt. The companies were operated firstly by four corporation and then by two corporations in order to expedite the economic development of the country. Similarly different industries were nationalized to accelerate the development in a newly independent country 
but the result was not up to expected level. Insurance companies were not incurred losses like other industrial units but their performance were not satisfactory at all. Privatization brings development in different countries. So, in 1984, the private initiatives in insurance business were permitted to compete with the existing Govt. owned Life insurance company (Jiban Bima Corporation) and General Insurance Company (Sadharan Bima Corportaion) and Foreign Insurance Company like American Life Insurance Company (ALICO). New insurance companies are established to support the business and cover the risk of lives and assets by strategically attractive plans. Gradually, 19 life insurance companies and 44 general insurance companies were established after 1984 in private initiatives. The growth in insurance business is calculated as $13 \%$ while in bank industry it is only $3 \%$. The insurance companies contributed more in strengthening the capital market of the country.

The lapse ratio of insurance in our country is found comparatively higher because of some demographic, financial and psychological factors of policy holders and failure of management in achieving required confidence of the prospective customers to attract and restore them for the longer period up to maturity.

The researchers seek to study the impact of demographic and financial factors of policy holders and operational policy of the insurers in maintaining better relationship over time that may contribute more in the growth of insurance business of the prospective market of 160 million population of Bangladesh. Besides the legal aspects of the country is to be checked in the evolution of insurance business in the country.

\section{Literature REVIEW}

Insurance shifts risks and enable individuals to involve in risky activities. (Ahsan et al. 1982). Risk is defined as the uncertainty of loss. The variations of outcomes of an event of chance are referred to as risk (Dake 1991). Insurance business contributes to economic development of a country by financial intermediary, risk transfer and indemnification, manage different risks and mobilize domestic savings (Ansary 2012). Though the growth ratio of insurance industry is satisfactory, the potentiality of insurance business is very high in Bangladesh. Actually, the attitudes to insurance business depend on the basic socio demographic and economic factors of citizens (Gautam and Kumar 2012). The insurance penetration ratio refers to the insurance premium divided by the percent of gross domestic products GDP indicates the attitude toward insurance in a country. It is more identified by the average insurance density that can be calculated by per capita premium income of a country. In Bangladesh the life insurance penetration ratio is found as 0.08 against that in India as 4.0 per cent. The average insurance density also shows a great gap and high potentiality of insurance business. This ratio is found in Bangladesh US\$ 5.5 against 41.2 dollar in India in 2008. To utilize the potentiality, the insurance Act 1938 was drastically changed in 2010 by including 50 rules and regulations to ensure the smooth flow of insurance business and security of lives and assets of the citizens by insurance coverage. The insurance Development and Regulatory Authority Act (IDRA), 2010 was implemented from January 2011. Framed by Insurance Corporation Act 1973, the state owned life insurance company (Jiban Bima Corporation JBC) enjoyed monopoly business opportunity up to 1984 and did not have concern for the interest of policyholders. It is found that liberalization in insurance and deregulation in insurance business brought positive impacts in Korean and Philippines life insurance companies and failed to bring significant result in Taiwanese and Thai life insurance Companies. (Boonyasai, Grace and Skipper 2002). In today's competitive market service is regarded as a strategic tool of success ((Kony and Jogaratnam, 2007). Insurance companies have to identify customers' need for their intangible product (Sedighiyan, 2000). The quality of service is an effective tool in creating competitive advantages and improvement. Is is found that there is a strong relationship between service quality, customer satisfaction and economic success (Tsoukatos and Rand, 2007). In Bangladesh the impact of nationalization and liberalization is to be studied in respect of companies' efficiency in creating awareness towards insurance and contribute in economic development.

According to Insurance Act all the insurance of Government owned entities must select Govt. owned companies for insurance. Besides, the reinsurance must be done through Govt. owned insurance company. So they are utilizing monopoly power in insurance business (Chowdhury, Rahman and Afzq 2007). It is found that monopoly in insurance business created by Govt. failed to get customers' satisfaction by customer relationship management (Karimi 2005). The human resources of JBC are not capable to increase the business because of their lower education and training level, attitudes and positions. According to insurance Act 2010 many insurer have not arranged sufficient amount of fund 
to conduct the business legally. Another state owned insurance company general insurance company (Sadharan Bima Corporation SBC) is performing poorly despite monopoly power of reinsuring and getting opportunity of doing policy of Govt. owned other enterprises. Around 70\% of its premium income is from reinsurance and $20 \%$ from other SOEs because of that monopoly power (Ahmed 2013). Due to the long negligence and harassment of customers by the insurance companies due to their monopoly power, it is now important to remove the poor image by hard work of employees of private insurance companies (Challis 1999) to utilize the potentialities of that market.

\section{OBJECTIVE}

The main objective of the study is to find out the impact of demographic, financial and managerial factors in growth of insurance business in Bangladesh. The specific objectives are:

- Examine the evolution of insurance business in Bangladesh with reference to legal aspects.

- To find out the impact of demographic factors such as age, gender, marital status etc on continuity of policy that contribute in the growth of insurance business

- To study the impact of financial factors such as profession, income etc on continuity of policy that contribute in the growth of insurance business

- To study the impact of managerial factors such as disclosure of term and conditions, notification, personal contact, customer satisfaction etc on continuity of policy that contribute in the growth of insurance business

\section{RESEARCH METHODOLOGY}

Research Design: This is a descriptive analytical research conducted by empirical analysis. The research was designed to conduct by survey method through questionnaire technique.

Sampling design: The research was conducted by stratified sampling technique to get the representation of policyholders, knowledgeable persons from different professions.

Reliability and Validity: The reliability of questionnaire was censured by checking the Cronbatch alpha (.71) and the validity by the positive opinion of senior researchers on insurance and risk management.

Data Collection: The data were collected from 182 respondents from April to August 2015 by door to door method. The sample size is determined by using appropriate statistical method. The secondary data were collected from journals, newspaper, articles and websites.

Data Analysis: the collected data was duly processed by SPSS 19 and analyzed by the use of percentile, simple statistical method, cross tabulation, chi-square analysis etc.

\section{FINDINGS}

\subsection{The Performance of Insurance Companies and the Legal Framework}

The experience of poor performance so insurance industry in the region of state monopoly since 1984, this industry is still remain very small with US $\$ 814$ million premium in $2009(.02 \%$ of share in global insurance industry). The penetration ratio is only $.09 \%$ and per capita spending is only US \$ 5.2. Though the growth in life insurance is $26.7 \%$ and is $10.4 \%$ in non life insurance. The private insurance companies enjoyed an impressive growth of premium of $19.2 \%$ in 2010 with an amount of US \$ 0.684 billion and made an investment of US \$ 1.42 billion with a growth rate of $29.97 \%$. The assets of private insurance companies are also increased by $29.58 \%$ in 2010 . The growth of non life private insurance is also tremendous $21.16 \%$ in premium. The total assets of non life private insurance stood at Tk 33.37 billion in against Govt. owned Sadaran Bima Corporation's asset of only Tk 11.21 billion at that time. (Rashid 2012).

From these statistics it is apparent that liberalization paved a bright future of insurance business in a prospective market where utilization is still very low. From the inspiring result of liberalization and to control the activities of present 77 insurance companies two laws were passed in the parliament in 2010; the Insurance Act 2010 and IDRA (Insurance Development and Regulatory Authority) 2010. The insurance Act 2010 harmonized different laws in socio-economic aspects of the country to protect the interest of stakeholders and strengthen this industry more by manage properly. IDRA was established by laws as a strong regulatory body to regulate, supervise and guide the insurance companies of the country. 
By comparing with other countries, it is easily assumed that our industry is more prospective. There are problems in management, marketing and Financial management. Poor governance, lack of innovative products, pricing, and promotion, poor financial base due to low premium that leads to poor risk bearing ability are the problems of insurance industry. Corruption in premium accounts, claim settlement and payments hampered the interests of the policy holders. The new laws and policy (Bima Niti 2014) addresses many limitations to increase the confidence of prospective policyholders but lacks some aspects those may leads to deprivation of the losing party, inclusion of incompetent sellers, less incentives to broadening products, managerial problems etc. The deprivation of policyholders may be increased due to absence of sufficient provision to punishment for breach of laws is not according to gravity of offences and financial damages (Section 130), insufficiency in definition of family (Sec 2.18), no specific authority to IDRA in case of fraud and malpractices and lack of Quasi-Judicial authority to protect undue practices of insurance companies (sections 24 and 25 of the IDRA Act 2010). The inclusion of incompetent sellers may arise from no provision of establishment of institutions to provide training to the personnel (Sec $124 \& 125$ ), scope of appointing politically biased person by using the provision of less than 20 years experienced persons (Section 7 of IDRA Act 2010), Scope of approving new insurance company on political ground. Limitations in expanding products and services in the new law is mentioned as there are no indication in broadening the area of life insurance or compulsory health insurance. The managerial and supervision problems may arise due to), no clear procedure of reporting to Bangladesh Financial Intelligence Unit (BFIU). The managerial problems, the provision of vacancy in CEO for at most three months may invite stagnation (Sec 80.4) no mention of expenditure range that result in tax evasion and money laundering, and pluralities of laws that may create difficulty, ambiguity and confusions.

\subsection{Analysis of Empirical Data on Policyholders' Attitudes}

The analysis is to get the causes of lapse ratio in insurance policy distributed by demographic, professional, financial and other factors.

Table1. Continuation of policy over years by the policyholders of different ages

\begin{tabular}{|c|c|c|c|c|c|c|c|c|}
\hline \multirow{2}{*}{\multicolumn{2}{|c|}{ Age: }} & \multicolumn{6}{|c|}{ Continuation of policy over years by the policyholders } & \multirow{3}{*}{$\begin{array}{l}\text { Total } \\
2 \\
\end{array}$} \\
\hline & & \multirow{2}{*}{$\begin{array}{ll}\text { No } \\
1 \\
\end{array}$} & \multirow{2}{*}{$\begin{array}{l}\text { less than } 2 y \\
1\end{array}$} & \multirow{2}{*}{$\begin{array}{l}2-5 \text { years } \\
0 \\
\end{array}$} & \multirow{2}{*}{$\begin{array}{l}5-10 \text { years } \\
0\end{array}$} & \multirow{2}{*}{$\begin{array}{l}10-15 \text { year } \\
0\end{array}$} & \multirow{2}{*}{$\begin{array}{l}\text { 15-above } \\
0\end{array}$} & \\
\hline 0 & Count & & & & & & & \\
\hline & Proportion & $50.0 \%$ & $50.0 \%$ & $.0 \%$ & $.0 \%$ & $.0 \%$ & $.0 \%$ & $100.0 \%$ \\
\hline \multirow[t]{2}{*}{ Less than 30} & Count & 22 & 25 & 24 & 15 & 3 & 1 & 90 \\
\hline & Proportion & $24.4 \%$ & $27.8 \%$ & $26.7 \%$ & $16.7 \%$ & $3.3 \%$ & $1.1 \%$ & $100.0 \%$ \\
\hline \multirow[t]{2}{*}{$30-40$} & Count & 14 & 5 & 31 & 7 & 0 & 0 & 57 \\
\hline & Proportion & $24.6 \%$ & $8.8 \%$ & $54.4 \%$ & $12.3 \%$ & $.0 \%$ & $.0 \%$ & $100.0 \%$ \\
\hline \multirow[t]{2}{*}{$40-50$} & Count & 5 & 3 & 6 & 8 & 4 & 0 & 26 \\
\hline & Proportion & $19.2 \%$ & $11.5 \%$ & $23.1 \%$ & $30.8 \%$ & $15.4 \%$ & $.0 \%$ & $100.0 \%$ \\
\hline \multirow[t]{2}{*}{ Above 50} & Count & 2 & 0 & 3 & 2 & 1 & 0 & 8 \\
\hline & Proportion & $25.0 \%$ & $.0 \%$ & $37.5 \%$ & $25.0 \%$ & $12.5 \%$ & $.0 \%$ & $100.0 \%$ \\
\hline \multirow[t]{2}{*}{ Total } & Count & 44 & 34 & 64 & 32 & 8 & 1 & 183 \\
\hline & Proportion & $24.0 \%$ & $18.6 \%$ & $35.0 \%$ & $17.5 \%$ & $4.4 \%$ & $.5 \%$ & $100.0 \%$ \\
\hline
\end{tabular}

Source: Field Survey

Dealing with the same insurance company for times indicates the reliability, confidence and satisfaction on that company. Any doubt about the trustworthiness on the company may lead the policy holders to switch to other company. Different age groups people have different extend of confidence, attitudes to switch. Naturally the senior people have more tolerance limit to stay with one company for long time what the juniors' lack. It is found that out of 183 respondents of whom $76 \%$ are policy holders and the rest $24 \%$ have the knowledge on insurance to share their feelings, the highest proportion (35\%) have the relationship with single company for 2-5 years that is followed by the respondents who have relationship for less than 2 years by $18.6 \%$. The $5-10$ years group is also insignificant to discuss as they follow the less 2 years group by a small difference $(17.5 \%)$. The longest relationship (5-10 years) with single company is dominant among 40-50 years age group as this group more matured and supposed to have more practical knowledge with moderate level of optimism and less attitude of switching over. The relationship with single company for 2-5 years is found among people of 30-40 years age group. But the people of above 50 also have a better proportion $(37.5 \%)$. The less than 2 years relationship found in less than 30 age group because of more satisfaction requiring attitudes lead them to frequent switching over. 
The chi square test verifies that logical reason for rejecting the null hypothesis that there is no difference in maintaining relationship with single insurance company for different time periods $\left(\chi^{2}=37.209, \mathrm{df}=20\right.$ and $\mathrm{p}$-value .011$)$. So it is established that policy holders' age is a significant determinant in maintaining relationship with a single company for different period.

Table2. Continuation of policy over years by the policyholders of different genders

\begin{tabular}{|c|c|c|c|c|c|c|c|c|}
\hline & \multicolumn{6}{|c|}{ Continuation of policy over years by the policyholders of different genders } & \multirow[t]{2}{*}{ Total } \\
\hline & & 0 & less than 2 & $2-5$ years & $5-10$ years & $10-15$ & $>15$ Years & \\
\hline \multirow[t]{2}{*}{ Male } & Count & 25 & 20 & 36 & 18 & 3 & 1 & 102 \\
\hline & Proportion & $24.0 \%$ & $19.6 \%$ & $35.3 \%$ & $17.6 \%$ & $2.9 \%$ & $1.0 \%$ & $100.0 \%$ \\
\hline \multirow[t]{4}{*}{ Female } & Count & 19 & 14 & 28 & 14 & 5 & 0 & 80 \\
\hline & Proportion & $23.8 \%$ & $17.5 \%$ & $35.0 \%$ & $17.5 \%$ & $6.3 \%$ & $.0 \%$ & $100.0 \%$ \\
\hline & Count & 44 & 34 & 64 & 32 & 8 & 1 & 183 \\
\hline & Proportion & $24.0 \%$ & $18.6 \%$ & $35.0 \%$ & $17.5 \%$ & $4.4 \%$ & $.5 \%$ & $100.0 \%$ \\
\hline
\end{tabular}

Source: Field Survey

Searching the attitudes of maintaining long term relationship with a single company between different genders of policy holders, it is found that among 102 male and 80 female respondents the duration of relationship is almost same. The highest proportion of male respondents $(35.3 \%)$ is found to maintain $2-5$ years relationship with a single company where the proportion of female is $35 \%$. This is followed by $19.6 \%$ of male who is holding less than 2 years relationship with a single company against $17.5 \%$ of female. In other duration, almost same proportion is found between male and female respondents.

To examine the significance of difference between male and female, the Chi-square test is used. By analyzing the outputs of Chi-square $\left(\chi^{2}=5.198, \mathrm{df}=10\right.$ and $\mathrm{p}$-value=.878) it can be inferred that there is no significant difference in the attitudes of maintaining relationship with single company for different periods.

Table3. Continuation of policy over years by the policyholders of different marital status

\begin{tabular}{|c|c|c|c|c|c|c|c|c|}
\hline \multirow{2}{*}{\multicolumn{2}{|c|}{ Status }} & \multicolumn{6}{|c|}{$\begin{array}{l}\text { Continuation of policy over years by the policyholders of different } \\
\text { marital status }\end{array}$} & \multirow[t]{2}{*}{ Total } \\
\hline & & 0 & $\begin{array}{l}\text { less than } 2 \\
\text { years }\end{array}$ & $2-5$ years & $5-10$ years & $\begin{array}{l}\text { More than } 10 \\
\text { years }\end{array}$ & 5 & \\
\hline \multirow[t]{2}{*}{ Married } & Count & 24 & 9 & 45 & 23 & 5 & 0 & 107 \\
\hline & Proportion & $20.4 \%$ & $8.7 \%$ & $43.7 \%$ & $22.3 \%$ & $4.9 \%$ & $.0 \%$ & $100.0 \%$ \\
\hline \multirow[t]{2}{*}{ Unmarried } & Count & 17 & 23 & 17 & 8 & 1 & 1 & 67 \\
\hline & Proportion & $25.4 \%$ & $34.3 \%$ & $25.4 \%$ & $11.9 \%$ & $1.5 \%$ & $1.5 \%$ & $100.0 \%$ \\
\hline \multirow[t]{2}{*}{ Divorced } & Count & 3 & 2 & 1 & 1 & 0 & 0 & 7 \\
\hline & Proportion & $42.9 \%$ & $28.6 \%$ & $14.3 \%$ & $14.3 \%$ & $.0 \%$ & $.0 \%$ & $100.0 \%$ \\
\hline \multirow[t]{2}{*}{ Widow/er } & Count & 0 & 0 & 1 & 0 & 2 & 0 & 3 \\
\hline & Proportion & $.0 \%$ & $.0 \%$ & $33.3 \%$ & $.0 \%$ & $66.7 \%$ & $.0 \%$ & $100.0 \%$ \\
\hline \multirow[t]{2}{*}{ Total } & Count & 44 & 34 & 64 & 32 & 8 & 1 & 183 \\
\hline & Proportion & $24.0 \%$ & $18.6 \%$ & $35.0 \%$ & $17.5 \%$ & $4.4 \%$ & $.5 \%$ & $100.0 \%$ \\
\hline
\end{tabular}

Source: Field Survey

Marital status may be considered as another factor in maintaining relationship with single company for different periods. The tendency of maintaining longer relationship with a single insurance company is found more in married persons than the unmarried respondents. The married persons have more experience about the practical world and are supposed to be less optimistic than the unmarried persons. So they bear the attitudes of switching over less frequently. The SPSS output in the cross tabulation indicates 2-5 years relationship of 43/7\% married respondents against $25.4 \%$ unmarried persons. Similarly $22.3 \%$ of married respondents in 5-10 years relationship were found against $11.9 \%$ of unmarried respondents. The shorter relationship was found in unmarried respondents in larger proportion (34.3\% against $8.7 \%$ of married). The respondents of broken marriage group (both divorced and widow) give more weights to the married group to intensify the difference.

The chi-square test successfully proved the mentioned relationship in married and unmarried respondents in maintaining relationship with single insurance company for different period. It proved that there is significant difference between married and unmarried persons $\left(\chi^{2}=65.064, \mathrm{df}=20\right.$ and $\mathrm{p}$ value $=.000$ ) in that attitude. 
Abdul Latif et al.

Table4. Continuation of policy over years by the policyholders of different educational qualifications

\begin{tabular}{|c|c|c|c|c|c|c|c|c|}
\hline \multicolumn{2}{|c|}{ Educational Qualification: } & \multicolumn{6}{|c|}{ dealing with specific insurance company for the how many years } & Total \\
\hline $\mathrm{No}$ & Count & 0 & 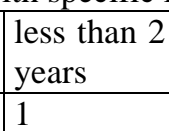 & \begin{tabular}{|l|}
$2-5$ years \\
1
\end{tabular} & \begin{tabular}{|l|}
$5-10$ years \\
5 \\
\end{tabular} & \begin{tabular}{|l} 
More than \\
10 years
\end{tabular} & 5 & 8 \\
\hline & Proportion & $12.5 \%$ & $12.5 \%$ & $12.5 \%$ & $62.5 \%$ & $.0 \%$ & $.0 \%$ & $100.0 \%$ \\
\hline \multirow[t]{2}{*}{ Up to HSC } & Count & 10 & 4 & 7 & 0 & 1 & 0 & 22 \\
\hline & Proportion & $45.5 \%$ & $18.2 \%$ & $31.8 \%$ & $.0 \%$ & $4.5 \%$ & $.0 \%$ & $100.0 \%$ \\
\hline \multirow[t]{2}{*}{ Undergraduate } & Count & 16 & 15 & 16 & 7 & 1 & 0 & 55 \\
\hline & Proportion & $29.1 \%$ & $27.3 \%$ & $29.1 \%$ & $12.7 \%$ & $1.8 \%$ & $.0 \%$ & $100.0 \%$ \\
\hline \multirow[t]{2}{*}{ Graduate } & Count & 14 & 12 & 29 & 17 & 6 & 1 & 79 \\
\hline & Proportion & $17.7 \%$ & $15.2 \%$ & $36.7 \%$ & $21.5 \%$ & $7.6 \%$ & $1.3 \%$ & $100.0 \%$ \\
\hline \multirow[t]{2}{*}{ Post Graduate } & Count & 3 & 2 & 11 & 3 & 0 & 0 & 18 \\
\hline & Proportion & $16.7 \%$ & $11.1 \%$ & $55.6 \%$ & $16.7 \%$ & $.0 \%$ & $.0 \%$ & $100.0 \%$ \\
\hline \multirow[t]{2}{*}{ Total } & Count & 44 & 34 & 64 & 32 & 8 & 1 & 183 \\
\hline & Proportion & $24.0 \%$ & $18.6 \%$ & $35.0 \%$ & $17.5 \%$ & $4.4 \%$ & $.5 \%$ & $100.0 \%$ \\
\hline
\end{tabular}

Source: Field Survey

Education makes people more informative and realistic. It is found that the tendency to maintain longer relationship with single company is found in more educated respondents. The 31/8\% respondents of HSC level is found in maintaining 2-5 years relationship whereas in post-graduation level it is increased to 55/6\%. No respondents of HSC level is found in maintaining the relationship with single insurance company for 5-10 years but from graduate respondent, this proportion is found as $21.5 \%$. Thus the tendency of maintaining longer relationship with single insurance company is found more in highly educated respondents than the less educated persons.

The chi-square test proved a moderate level of significant difference $\left(\chi^{2}=35.956, \mathrm{df}=25\right.$ and $\mathrm{p}$ value $=.050$ ) among respondents with different levels of education. The highly educated persons are shown in maintaining relationship with same company for longer period than the less educated persons.

Table5. Continuation of policy over years by the policyholders of different occupations

\begin{tabular}{|c|c|c|c|c|c|c|c|c|}
\hline & \multicolumn{6}{|c|}{ dealing with specific insurance company for the how many years } & \multirow[t]{2}{*}{ Total } \\
\hline & & 0 & $\begin{array}{l}\text { less than } 2 \\
\text { years }\end{array}$ & $2-5$ years & $5-10$ years & $\begin{array}{l}\text { More than } \\
10 \text { years }\end{array}$ & 5 & \\
\hline \multirow[t]{2}{*}{ Public employee } & Count & 2 & 1 & 11 & 11 & 2 & 0 & 27 \\
\hline & Proportion & $7.4 \%$ & $3.7 \%$ & $40.7 \%$ & $40.7 \%$ & $7.4 \%$ & $.0 \%$ & $100.0 \%$ \\
\hline \multirow{2}{*}{$\begin{array}{l}\text { private } \\
\text { Employee }\end{array}$} & Count & 18 & 15 & 23 & 9 & 3 & 0 & 63 \\
\hline & Proportion & $22.2 \%$ & $22.2 \%$ & $36.5 \%$ & $14.3 \%$ & $4.8 \%$ & $.0 \%$ & $100.0 \%$ \\
\hline \multirow[t]{2}{*}{ Businessmen } & Count & 15 & 16 & 24 & 10 & 0 & 1 & 62 \\
\hline & Proportion & $19.4 \%$ & $24.2 \%$ & $38.7 \%$ & $16.1 \%$ & $.0 \%$ & $1.6 \%$ & $100.0 \%$ \\
\hline \multirow{2}{*}{$\begin{array}{l}\text { Retired } \\
\text { Employee }\end{array}$} & Count & 1 & 1 & 3 & 2 & 2 & 0 & 9 \\
\hline & Proportion & $11.1 \%$ & $11.1 \%$ & $33.3 \%$ & $22.2 \%$ & $22.2 \%$ & $.0 \%$ & $100.0 \%$ \\
\hline \multirow{2}{*}{$\begin{array}{l}\text { High Skilled } \\
\text { Professionals }\end{array}$} & Count & 9 & 1 & 3 & 0 & 0 & 0 & 12 \\
\hline & Proportion & $66.7 \%$ & $8.3 \%$ & $25.0 \%$ & $.0 \%$ & $.0 \%$ & $.0 \%$ & $100.0 \%$ \\
\hline \multirow[t]{2}{*}{ Total } & Count & 44 & 34 & 64 & 32 & 8 & 1 & 183 \\
\hline & Proportion & $24.0 \%$ & $18.6 \%$ & $35.0 \%$ & $17.5 \%$ & $4.4 \%$ & $.5 \%$ & $100.0 \%$ \\
\hline
\end{tabular}

Source: Field Survey

Searching the tendency of dealing with specific insurance company by different professionals, it is found that highest proportion of public employees are maintaining longer relationship with specific company, it may because of the more stable income of public employee. The second highest proportions of people are found to maintain longer relationships with specific company are retired persons. The larger proportion of businessmen are found to maintain relationship with specific company for shorter period (less than 2 years)

The Chi-Square test verifies the significant difference in maintaining longer relationship with specific company by different professionals (c; public employees, private employees, businessmen, retired persons and high skilled persons. 
The Demographic, Legal and Managerial Aspects in the Growth of Insurance Business in Bangladesh

Table6. Continuation of policy over years by the policyholders of different monthly income

\begin{tabular}{|c|c|c|c|c|c|c|c|c|}
\hline & \multicolumn{6}{|c|}{ dealing with specific insurance company for the how many years } & \multirow[t]{2}{*}{ Total } \\
\hline & & 0 & $\begin{array}{l}\text { less than } 2 \\
\text { years }\end{array}$ & $\begin{array}{l}2-5 \\
\text { years }\end{array}$ & $\begin{array}{l}5-10 \\
\text { years }\end{array}$ & $\begin{array}{l}\text { More than } \\
10 \text { years }\end{array}$ & 5 & \\
\hline \multirow[t]{2}{*}{ below 20000} & Count & 18 & 17 & 12 & 2 & 2 & 0 & 47 \\
\hline & Proportion & $31.9 \%$ & $34.0 \%$ & $25.5 \%$ & $4.3 \%$ & $4.3 \%$ & $.0 \%$ & $100.0 \%$ \\
\hline \multirow[t]{2}{*}{$20000-40000$} & Count & 19 & 14 & 40 & 21 & 5 & 1 & 93 \\
\hline & Proportion & $15.1 \%$ & $14.0 \%$ & $43.0 \%$ & $22.6 \%$ & $4.3 \%$ & $1.1 \%$ & $100.0 \%$ \\
\hline \multirow[t]{2}{*}{$40000-80000$} & Count & 6 & 2 & 10 & 9 & 0 & 0 & 26 \\
\hline & Proportion & $19.2 \%$ & $7.7 \%$ & $38.5 \%$ & $34.6 \%$ & $.0 \%$ & $.0 \%$ & $100.0 \%$ \\
\hline \multirow[t]{2}{*}{ More than 80000} & Count & 1 & 1 & 2 & 0 & 1 & 0 & 5 \\
\hline & Proportion & $20.0 \%$ & $20.0 \%$ & $40.0 \%$ & $.0 \%$ & $20.0 \%$ & $.0 \%$ & $100.0 \%$ \\
\hline \multirow[t]{2}{*}{ Total } & Count & 44 & 34 & 64 & 32 & 8 & 1 & 183 \\
\hline & Proportion & $24.0 \%$ & $18.6 \%$ & $35.0 \%$ & $17.5 \%$ & $4.4 \%$ & $.5 \%$ & $100.0 \%$ \\
\hline
\end{tabular}

Source: Field Survey

Naturally people with higher income tend to continue the policy with single company because of their less tension about depositing premium and about the security of their deposited money. This amount is considered as a small amount of their income. It is found that people with higher income have a tendency of continuing with specific company for longer period and lower income for comparatively shorter period. The lower income people face the problem of depositing the premium on time sometimes that leads to stoppage of the policy. Again at the time of solvency they may open another policy with new company because of more convenient terms and conditions. Thus switching to different companies in shorter period may be held frequently by comparatively lower income people than the higher income people. In this research, it is found that $20 \%$ of higher income people (Above 80000 monthly) is dealing with a specific company for more than 10 years whereas only $4.3 \%$ of lower income people (Tk. 20000 monthly) was able to do it. It is reversed in case of relationship for shorter period (less than 2 years).

By examining the significance of difference among different income group in maintaining relationship with specific insurance company, Chi-square test is used. The result of Chi-square test $\left(\chi^{2}=53.732, \mathrm{df}=25\right.$ and $\mathrm{p}$-value $\left.=.001\right)$ reveals that there is significant difference among different income group in maintaining relationship with specific company for different periods.

Table7. Reasons for policy

\begin{tabular}{|l|l|l|l|l|l|}
\hline Importance & \multicolumn{4}{l|}{ Periodicity of Premium } \\
\hline Factors & Frequency & Percent & Periods & Frequency & Percent \\
\hline Risk Cover & 17 & 9.3 & 0 & 42 & 23.0 \\
\hline Tax saving & 9 & 4.9 & Monthly & 45 & 24.0 \\
\hline Investment & 9 & 4.9 & Quarterly & 33 & 18.0 \\
\hline Confidence Building & 3 & 1.6 & Semi-annually & 21 & 11.5 \\
\hline All of them & 102 & 55.7 & Annually & 42 & 23.0 \\
\hline Total & 183 & 100.0 & Total & 183 & 100.0 \\
\hline
\end{tabular}

Source: Field Survey

The economic security by covering risks, taking the advantages of tax exemption, invest the savings in profitable venture, protection of personal property from uncertainty etc. are the main reasons for starting insurance policies. It is found that, the respondents have opened the policies to meet all the mentioned reasons $(55.7 \%)$. The most significant single reason is covering the risk of lives and assets $(9.3 \%)$ that is followed by other single reasons.

Table8. Comparison of cost of insurance at private companies against public companies

\begin{tabular}{|l|l|l|l|}
\hline & Frequency & Percent & Cumulative Percent \\
\hline No response & 5 & 2.7 & 2.7 \\
\hline very Cheap & 12 & 6.6 & 9.3 \\
\hline Cheap & 42 & 23.0 & 32.2 \\
\hline At par & 91 & 49.7 & 82.0 \\
\hline Expensive & 27 & 14.8 & 96.7 \\
\hline More Expensive & 6 & 3.3 & 100.0 \\
\hline Total & 183 & 100.0 & \\
\hline
\end{tabular}

Source: Field Survey 
After the liberation of Bangladesh, the insurance business was controlled by two state owned companies. But on the basis of The Insurance Amendment Ordinance 1984, many private insurance companies have started their operation. So far, 19 life insurance and 43 general insurance companies were established. So the flourishing of insurance businesses are now depends on the private insurance companies. The research was done to find out the reasons for dominance of private insurance companies from very cheap premium to very expensive premium. But almost 50\% (49.7\%) of respondents believe that there is no supremacy of private companies over public companies in respect of rate of premium. The $23 \%$ of the respondents opined that rate premium in private companies are cheaper than that of private companies for any certain level of risk that is followed by $14.8 \%$ respondents who thought it is expensive. From that analysis, we can conclude that majority of respondents perceive that the rate of premium is similar in both type of companies. So, the supremacy may depend on other factors.

Table9. Factors of Purchase Decision \& Main Reason to sticking with Specific Company

\begin{tabular}{|c|c|c|c|c|c|c|c|}
\hline & Factors & Frequency & Percent & & Factors & Freq & $\%$ \\
\hline \multirow{7}{*}{$\begin{array}{l}\text { Factors of } \\
\text { Purchase } \\
\text { Decision }\end{array}$} & No answer & 32 & 32 & & No & 44 & 24.0 \\
\hline & \begin{tabular}{|l|} 
Visit of Insurance Agent \\
\end{tabular} & 48 & 26.23 & \multirow{6}{*}{$\begin{array}{l}\text { Main } \\
\text { Reason to } \\
\text { sticking } \\
\text { with } \\
\text { specific } \\
\text { Company }\end{array}$} & Quality & 18 & 9.8 \\
\hline & General Advertising & 46 & 25.14 & & Less premium & 9 & 4.9 \\
\hline & Direct Mail Advertising & 9 & 4.92 & & Better Terms & 10 & 5.5 \\
\hline & Word of mouth & 24 & 13.11 & & Better office & 7 & 3.8 \\
\hline & Newspaper Report \& others & 23 & 12.57 & & All of them & 94 & 51.4 \\
\hline & Total & 182 & 99.45 & & Total & 182 & 99.5 \\
\hline
\end{tabular}

Source: Field Survey

To find out the main motivation for purchasing insurance policy, the factors studies are: visits of insurance agent, general advertisement, direct mail advertising, word of mouth, newspaper report \& others. It is found that most of the policy holders were attracted by visits of agents, brokers (26.23\%) that are very closely followed by advertisement (25.14\%) and word of mouth (13.11\%). So the aggressive activities of private insurance agents and brokers have greater contribution in attracting more business for such firms. The reason for attracting with specific companies and continuation of policy depends on quality of service, lower premium, better terms and conditions, attractive offices etc. It is also found that clients consider all the factors for attraction to such companies (51.4\%). The single most important factor is quality of services $(9.8 \%)$.

Table10. Reactions to Service Quality

\begin{tabular}{|l|l|l|l|l|l|l|l|l|}
\hline & No Response & Excellent & Good & Average & Bad & Very Bad & System & Total \\
\hline $\begin{array}{l}\text { Quality of Service of } \\
\text { private Company }\end{array}$ & 4 & 31 & 64 & 49 & 31 & 4 & & 183 \\
\hline & 2.2 & 16.9 & 35 & 26.8 & 16.9 & 2.2 & & 100 \\
\hline $\begin{array}{l}\text { Satisfactions on } \\
\text { performance of private } \\
\text { Insurance Company }\end{array}$ & 3 & 45 & 71 & 34 & 23 & 6 & 1 & 183 \\
\cline { 2 - 9 } & 1.6 & 24.6 & 38.3 & 18.6 & 12.6 & 3.3 & 0.5 & 100 \\
\hline
\end{tabular}

Source: Field Survey

The majority of the respondents $(35 \%)$ consider the quality of service of private insurance companies as a good and $26.8 \%$ consider the service as indifferent by comparing with the services of public insurance companies. The proportion of respondents considers those services as excellent and as bad are equal (16.9\%). But the satisfaction derived from the company indicates a different result. Most of the respondents (38.3\%) are satisfied on the existing service quality indicates the policy holders and respondents are realistic, not too much optimistic. The second largest proportion of respondents considers their satisfaction level as highly satisfied (24.6\%).

Table11. Reaction of Policyholders on different aspects of Insurers' performance

\begin{tabular}{|l|l|l|l|l|l|l|l|}
\hline & No Response & $\begin{array}{l}\text { Strongly } \\
\text { Agree }\end{array}$ & Agree & Neutral & Disagree & $\begin{array}{l}\text { Strongly } \\
\text { disagreed }\end{array}$ & Total \\
\hline \multirow{2}{*}{$\begin{array}{l}\text { Must need a policy to meet } \\
\text { uncertainty }\end{array}$} & & 4 & 43 & 83 & 23 & 24 & 6 \\
\hline & & 2.2 & 23.5 & 45.4 & 12.6 & 13.1 & 3.3 \\
\hline $\begin{array}{l}\text { Need protection due to } \\
\text { uncertainty }\end{array}$ & & 33 & 84 & 41 & 18 & 6 & 182 \\
\hline Sufficiency of Consumer & & 18 & 45.9 & 22.4 & 9.8 & 3.3 & 99.5 \\
\hline
\end{tabular}


The Demographic, Legal and Managerial Aspects in the Growth of Insurance Business in Bangladesh

\begin{tabular}{|c|c|c|c|c|c|c|c|}
\hline protection Act & & 21.3 & 41.5 & 23.5 & 11.5 & 1.6 & 99.5 \\
\hline \multirow{2}{*}{$\begin{array}{l}\text { No Heed to consumer protection } \\
\text { act by private companies }\end{array}$} & 1 & 64 & 45 & 41 & 24 & 7 & 182 \\
\hline & 0.5 & 35 & 24.6 & 22.4 & 13.1 & 3.8 & 99.5 \\
\hline \multirow[t]{2}{*}{ Poor Service Quality } & & 39 & 65 & 57 & 13 & 8 & 182 \\
\hline & & 21.3 & 35.5 & 31.1 & 7.1 & 4.4 & 99.5 \\
\hline \multirow{2}{*}{$\begin{array}{l}\text { Non disclosure by agents or } \\
\text { broker }\end{array}$} & 3 & 49 & 58 & 38 & 23 & 11 & 182 \\
\hline & 1.6 & 26.8 & 31.7 & 20.8 & 12.6 & 6 & 99.5 \\
\hline \multirow{2}{*}{$\begin{array}{l}\text { Explanation of terms and } \\
\text { conditions }\end{array}$} & & 33 & 72 & 53 & 17 & 7 & 182 \\
\hline & & 18 & 39.3 & 29 & 9.3 & 3.8 & 99.5 \\
\hline \multirow[t]{2}{*}{ Understandable products } & & 44 & 76 & 40 & 15 & 7 & 182 \\
\hline & & 24 & 41.5 & 21.9 & 8.2 & 3.8 & 99.5 \\
\hline \multirow{2}{*}{$\begin{array}{l}\text { Understandable Broachers } \\
\text { language }\end{array}$} & 2 & 31 & 70 & 55 & 21 & 3 & 182 \\
\hline & \begin{tabular}{|l|}
1.1 \\
\end{tabular} & 16.9 & 38.3 & 30.1 & 11.5 & 1.6 & 99.5 \\
\hline \multirow{2}{*}{$\begin{array}{l}\text { Late in notifying leads to failure } \\
\text { in payment }\end{array}$} & 2 & 47 & 58 & 44 & 22 & 9 & 182 \\
\hline & \begin{tabular}{|l|}
1.1 \\
\end{tabular} & 25.7 & 31.7 & 24 & 12 & 4.9 & 99.5 \\
\hline \multirow[t]{2}{*}{ Failure due to unpaid premium } & 1 & 37 & 53 & 59 & 19 & 13 & 182 \\
\hline & 0.5 & 20.2 & 29 & 32.2 & 10.4 & 7.1 & 99.5 \\
\hline \multirow[t]{2}{*}{ Delay in decision to claims } & 2 & 41 & 60 & 50 & 17 & 12 & 182 \\
\hline & \begin{tabular}{|l|}
1.1 \\
\end{tabular} & 22.4 & 32.8 & 27.3 & 9.3 & 6.6 & 99.5 \\
\hline \multirow[t]{2}{*}{ Immediate final payment } & 8 & 47 & 63 & 39 & 15 & 10 & 182 \\
\hline & \begin{tabular}{|l}
4.4 \\
\end{tabular} & 25.7 & 34.4 & 21.3 & 8.2 & 5.5 & 99.5 \\
\hline \multirow[t]{2}{*}{ Deals Should be with one Co. } & 5 & 26 & 60 & 50 & 33 & 8 & 182 \\
\hline & 2.7 & 14.2 & 32.8 & 27.3 & 18 & 4.4 & 99.5 \\
\hline \multirow{2}{*}{$\begin{array}{l}\text { Private Companies Affect } \\
\text { Public's Business }\end{array}$} & 1 & 21 & 37 & 84 & 27 & 11 & 1 \\
\hline & 0.5 & 11.5 & 20.2 & 45.9 & 14.8 & 6 & 0.5 \\
\hline \multirow[t]{2}{*}{ Scope Widened by private } & & 32 & 54 & 64 & 25 & 7 & 182 \\
\hline & & 17.5 & 29.5 & 35 & 13.7 & 3.8 & 99.5 \\
\hline \multirow[t]{2}{*}{ Competition Improved Public } & & 42 & 59 & 55 & 14 & 12 & 182 \\
\hline & & 23 & 32.2 & 30.1 & 7.7 & 6.6 & 99.5 \\
\hline
\end{tabular}

Source: Field Survey

Though most of the respondents (45.4\%) consider the importance of policy indifferently, $23.4 \%$ consider it as important. But highest proportion of respondents $(45.9 \%)$ needs a protection from uncertainty. To get the protection from insurance policy, the consumer right protection act is reviewed. The largest proportion $41.5 \%$ opined that this act is sufficient to protect the right of policy holders. But whether the companies are considering the act or not is the question. Most of the respondents perceive that (35\%) the companies pay no attention to the act and consumer rights. Regarding the service quality, the respondents $(35.5 \%)$ termed that as poor. For the insurance policy all the terms and conditioned are to be disclosed properly. It is the responsibility of broker or agents to disclose all to the prospects. But the respondents (58.5\%) opined that all the terms are not disclosed properly to the prospects before the agreements. A minimum proportion of respondents, possibly because of not properly understanding of the statement disagree that the product should be understandable and the language of brochure should be simple and easy to understand the products. Similarly, a small portion (16.9\%) disagree that late or no notification about payment of premium leads to the discontinuity of policy because of non-payment. Almost all the respondents (82.5\%) agree that this discontinuity of policy is due to the non-payment of premium timely. Delay in decision about claim adjustment is another reason for non-attraction to insurance policies. This is the perception of most of the respondents of Bangladesh. Only $15.9 \%$ of the sample disagree with the statement may be for lack of experience or proper treatment to them by the companies. Similarly except a small portion (13.7\%), all the respondents are anxious about the final payment from the insurance company. The perception of late payment is prevailing in the mind of all the respondents. Attachment to one company leads to successful completion of the period of insurance and getting a fruitful result in case of risk covering and final payment on maturity. So inclination with one company is considered as important by all the respondents with a small exception (22.4\%). The aggressive activities of private insurance companies affected business of Govt. owned insurance companies. All the respondents other than $20.8 \%$ opined that private insurance companies squeezed the businesses of public companies where customers' care is not in satisfactory level. But the private insurance companies are successful in creating more awareness about insurance among citizens and thus widened the scope of more business on insurance. Only $17.5 \%$ respondents showed their disagreement in this notion may 
be due to misunderstanding of the statement or different opinion on that issue. More important aspect of insurance industry is that due to the aggressive attitude of private insurance companies, the efficiency of Govt. owned insurance companies is also improved in some extent to face the competition in the industry.

Overall Discussion: Experience of operating the insurance business in the private then public and presently in public and private management in pre and post liberation period with necessary legal supports has given a chance to experiment on the effect of different management patterns. A large numbers of insurance companies (67 in both life and general insurance) were nationalized after liberation and had to work in two corporations; Jibon Bima Corporation (life insurance) and Sadaran Bima Corporation (general insurance). Observing the failure in flourishing the insurance industry by delivering services in optimum level by Govt. owned insurance companies; the legal stand was changed on 1984 to allow the private businesses in insurance industry. The two laws and insurance policy 2014 should includes and modify some chapters to improve the supervision and management quality by the regulatory authority, prevent the inclusion of incompetent sellers, pave the ways for improving qualities of sellers and remove the confusions due to pluralities of laws. From the survey on policy holders from different private insurance companies and knowledgeable citizens, it is found that private insurance companies squeezed the businesses of public insurance companies by attracting the clients through their better services but the total insurance businesses were expanded due to the awareness created by the extensive marketing of such companies. The public companies were failed to provide marketing activities in aggressive manner. But the policy holders are not satisfied fully because of the services of insurance companies is not reached at the optimum level. Many policy holders feels that there are limitations in disclosures of terms and conditions clearly to the prospects by the brokers or agents, proper notification about premium, timely claim settlement and payments etc. The continuation of policy to cover risk and get bonus and other benefits at the maturity needs to successful completion of the maturity period or till any unexpected accident. But the completion of insurance needs discharging the responsibilities (formalities) for the longer period with patience. Due to financial, physical or mental inability or any doubtful or unexpected behavior from the insurer, the relationship with insurer can be broken and the policy is failed. So the researchers studied the existence of relationship for different time durations between the insurer and policy holders. The distribution of policyholders on the basis of their age, gender, education, marital status, profession, income level etc is studied for that purpose. It is proved that education, experiences and maturity kept the policyholders attached with the insurer up to the maturity or for longer period. The level of age, education, marital status showed significant difference on success in keeping relationship with insurer for longer period due to the maturity and the profession and income level make distinction due to different level of financial ability. But the gender creates no difference in this respect. The main purpose of starting policy is to get all benefits of insurance by the policy holders. The difference between public and private insurance companies in respect of charging lower premium for the same benefits is not remarkable. So it can be inferred that intention of doing policy from private insurance is to get better service from private management. Continuation of policy by doing the formalities time to time for a longer period is attributed by better quality service, trustworthiness, lower charges and others. Personal selling is proved as a most effective method in influencing individuals to take unsought products along with advertisement in print and electronic media and the private insurance companies are far advanced in such promotional activities.

\section{Conclusion}

The legal aspects of insurance business are found as an important element in growth of insurance business. The permission to establish insurance business in private initiative contribute more in the flourish of that business though still more prospects of insurance business is laying forward. The awareness and confidence in insurance companies is to be established more by considering the demographic, financial elements of policy holders and managerial elements of insurers. The legal elements should be modified more to meet the challenges of coming world and its complicated problems. Besides the managerial aspects of insurance business is to be improved more to take the opportunity of huge insurance prospect in Bangladesh.

Managerial Implications: The legal support to insurance business is to be continued by modifying the acts time to time to meet the complicated problem that may hinder the growth of insurance business. The demographic factors are to be considered more by giving more emphasize to minimizing the 
switching over and discontinuations. The financial factors specially in case of depositing premium regularly are to be more flexible to help the policy holders in continuation of the policy in crisis period. The managerial aspects are to be dynamic in building the awareness and confidence on the insurer and provide highest satisfaction from the policy by giving services in expected levels.

Limitations: The research has the limitation in sample size and sampling frame for their narrow aspects. The widened sample size sampling frame could give more insights and help in generalizations of the findings. The factors considered are limited in number by considering the size of articles.

Further research: By expanding the sample size, sampling frame and factors, further researches could be done. A factor analysis on the discontinuation of policies can be conducted. The impact of legal aspects could be analyzed by secondary data analysis.

\section{REFERENCES}

Ahmed, Mohammad (2013). "The State of Insurance Industry in Bangladesh". Economic Observer. available at https://www.citethisforme.com/...marketing/Insurance\%20sector\%20of\%..

IDRA (2015), Insurance Development \& Regulatory Authority Bangladesh Web. Available at Idra.org.bd

Ansari Z. A. (2012) An empirical analysis of risk perception, remedial measures and behavior of people in Saudi Arabia towards insurance, African Journal of Business Management Vol. 6(10), pp. 3733-3744,

Ashan SM, Ali AAG, Kurian NJ (1982). Towards a theory of agricultural crop insurance. Am. J. Agric. Econ., 64(3): 520-529.

Boonyasai, T., Grace, F.M. and Skipper, H.D. (2002), "The Effect of Liberalization and Deregulation on the Life Insurers Efficiency", Center for Risk Management and Insurance Research Georgia State University Atlanta, GA, Working Paper No. 2.

Challis S (1999). A revolution in insurance. Reactions, 19(8): 5-8.

Dake K (1991). Disposition in the perception of risk; an analysis of contemporary worldviews and cultural basis. J. Cross. Cult. Psychol.

Gautam, V. and Kumar, M. (2012). A Study on Attitudes of Indian Consumers towards Insurance. Services Management Research and Practice, 4 (1), pp. 51-62.

Jatiya Bima Niti (2014), available at http://www.scribd.com/doc/196374678/Jatiyo-Bima-Niti2013\#scribd

Karimi A (2005). Techniques of selling professional insurance selling, Iran Central research Center Publications, first edition.

Kony M, Jogaratnam G (2007). "The influence of culture on perceptions of service employee behavior", Manag. Serv. Qual. 17(3):37-47.

Rashid, Mamun (2012). "Insurance Industry In Bangladesh: A Long Way To Go". The Financial express 2012: n. pag. Print.

Sedighiyan H (2000). Marketing management and insurance sale, Iran Insurance Publications, First edition.

Tsoukatos E, Rand K (2007)." cultural influences on service quality and customer satisfaction: evidence from Greek insurance", Manag. Serv. Qual. 17(4):467-485. 